\title{
Primary ectopic axillary breast cancer: a case series
}

\author{
S. Sghaier*, M. GHalleb, I. Marghli, A. Bouida, J. Ben Hassouna, R. Chargui and K. Rahal
}

\begin{abstract}
Introduction: Ectopic breast tissue is present in 2-6\% of women. Ectopic breast cancer represents an uncommon disease accounting for about $0.3 \%$ of all breast neoplasms, limiting the available evidence. Thus, we aim to report long-term outcomes in five cases treated at our institution.

Case series: Our Tunisian patients' median age was 48 years (33-60 years), and the median follow-up was 8 years (4-10 years). The ectopic breast tissue was located four times in the right axilla. The median tumor size was $25 \mathrm{~mm}$ $(15-55 \mathrm{~mm})$. Four of the patients underwent a wide local excision and axillary lymph node dissection. Three of those women had positive lymph nodes; thus, they received adjuvant chemotherapy, radiation therapy, and hormone therapy. The patient with a negative lymph node (case 5) had adjuvant radiation therapy and hormonal therapy. One of the patients (case 1) had a positive supraclavicular lymph node and received radiation therapy, chemotherapy, and hormonal therapy. The latter developed a locoregional relapse after 4 years and was treated with mastectomy and chemotherapy. One patient (case 4) had a distant metastasis after 2 years of follow-up and received chemotherapy. The three other patients were free of relapse during their follow-up period.
\end{abstract}

Conclusion: Primary axillary breast carcinoma is a rare entity. Despite the paucity of literature, our findings and authors'recommendations suggest that local excision can be performed safely with promising outcomes in this subset of patients.

Keywords: Ectopic breast tissue, Carcinoma, Surgery, Chemotherapy, Radiotherapy, Hormonotherapy

\section{Introduction}

Ectopic breast tissue is present in $2-6 \%$ of women, usually localized in the axilla $[1,2]$. This ectopic tissue may endure similar physiological and benign or malignant pathological variations that affect the normal breast tissue. The axilla represents the most common site, while the sternum area, the infraclavicular region, the epigastrium, and the vulva have also been described [1-3]. Breast cancer is the most common cancer in women, whereas ectopic breast cancer $(\mathrm{EBC})$ represents about $0.3 \%$ of all breast malignancies $[4,5]$. Like orthotopic breast carcinoma, the ductal subtype is the most frequent type, while the other histological types may also be present $[5,6]$. Surgical treatment consists of wide excision of the tumor with lymphadenectomy $[4,5,7]$. Concerning the adjuvant treatment of $\mathrm{EBC}$, it has the same indications as orthotropic breast carcinoma.

We aim to report our experience of long-term outcomes in five cases of EBC treated at our institution and to shed light on this rare occurrence.

\section{Case series (Table 1: Patients' characteristics)}

We report a case series of five Tunisian patients referred to Salah Azaiez Institute in Tunis for specialized care of EBC.

\footnotetext{
*Correspondence: Sarah.sghaier91@gmail.com

Surgical oncology department, Salah Azaiez Institute of cancer, Tunis,

Tunisia
} original author(s) and the source, provide a link to the Creative Commons licence, and indicate if changes were made. The images or other third party material in this article are included in the article's Creative Commons licence, unless indicated otherwise in a credit line to the material. If material is not included in the article's Creative Commons licence and your intended use is not permitted by statutory regulation or exceeds the permitted use, you will need to obtain permission directly from the copyright holder. To view a copy of this licence, visit http://creativecommons.org/licenses/by/4.0/. The Creative Commons Public Domain Dedication waiver (http://creativeco mmons.org/publicdomain/zero/1.0/) applies to the data made available in this article, unless otherwise stated in a credit line to the data. 
Table 1 Patients' characteristics

\begin{tabular}{|c|c|c|c|c|c|c|c|c|c|}
\hline Patients & Age & Chief complaint & Affected side & $\begin{array}{l}\text { Tumor } \\
\text { size } \\
(\mathrm{mm})\end{array}$ & TNM classification & Histologic findings & Surgery & RT & $\mathrm{CT}$ \\
\hline 1 & 60 & Nodule & Right & 55 & T3N3cM0 & $\begin{array}{l}\text { *ILC, grade II SBR, HR + } \\
\text { *Subclavicular node: + }\end{array}$ & No & Yes & FEC \\
\hline 2 & 48 & Nodule & Left & 20 & T2N1M0 & $\begin{array}{l}* \mid \mathrm{DC}, \text { grade }|| \mid \mathrm{SBR}, \mathrm{HR}-, \mathrm{HER} 2= \\
3+ \\
* 1 \mathrm{~N}+/ 13 \text { nodes }\end{array}$ & Wide excision + LND & Yes & FEC \\
\hline 3 & 53 & Nodule & Right & 30 & $\mathrm{~T} 2 \mathrm{~N} 1 \mathrm{M} 0$ & $\begin{array}{l}* 1 \mathrm{DC}, \text { grade } I I I S B R, H R-, \text { HER } \\
2=2+ \\
* 1 \mathrm{~N}+/ 13 \text { nodes }\end{array}$ & Wide excision+ LND & Yes & FEC \\
\hline 4 & 60 & Nodule & Right & 18 & T1N1M0 & $\begin{array}{l}\text { *IDC, grade } \| \mathrm{SBR}, \mathrm{HR}+ \\
\text { HER } 2=1+ \\
* 11 \mathrm{~N}+/ 13 \text { nodes }\end{array}$ & Wide excision + LND & Yes & FEC \\
\hline 5 & 33 & Nodule & Right & 30 & T2NOMO & $\begin{array}{l}{ }^{*} \mathrm{MC}, \mathrm{HR}- \\
{ }^{*} 9 \mathrm{~N}-/ 9 \text { nodes }\end{array}$ & Wide excision + LND & Yes & No \\
\hline
\end{tabular}

ILC invasive lobular carcinoma, IDC invasive ductal carcinoma, MC medullary carcinoma, HR hormonal receptors, HER2 human epidermal growth factor receptor, $N+$ or - positive or negative lymph node, $R T$ radiation therapy, $C T$ chemotherapy, $F E C 5$-fluorouracil + epirubicin + cyclophosphamide, $C M F$ cyclophosphamide + methotrexate + fluorouracil

\section{Case 1}

The patient, a 60-year-old Tunisian woman with no past medical history, presented to our consultation with a right axillary lump evolving for about 6 months.

Physical examination revealed a right axillary firm illdefined nodule of $55 \mathrm{~mm}$ in diameter. We also found firm ipsilateral axillary lymphadenopathies fixed together and suspicious supraclavicular lymph nodes. Breast examination found no apparent anomaly. Breast mammogram was regular.

There was no distant disease on computed tomography (CT) scan.

The patient underwent a core biopsy of the axillary nodule. The histopathological result was concordant with breast carcinoma. It was an invasive lobular carcinoma with a grade II of the Scarff-Bloom-Richardson (SBR) classification and positive hormonal receptors [estrogen receptor (ER), progesterone receptor (PR)]. The supraclavicular node was metastatic. The tumor was staged as T3N3cM0 according to the TNM system.

The decision was to administer six courses of 5-fluorouracil, epirubicin, cyclophosphamide (FEC)-based chemotherapy followed by locoregional radiotherapy (50 Gy are given to the right breast area, the right subclavicular fossa, and the right axilla with a subsequent boost of $12 \mathrm{~Gy}$ for the tumor bed) and hormone therapy by tamoxifen. After a satisfactory therapeutic response, we decided to perform a wide excision of the axillary nodule associated with a lymphadenectomy. However, after discussion with the patient, she preferred to remain closely monitored.

After a 4-year follow-up, the patient presented a right breast carcinoma classified as T2N1M0. She underwent a radical mastectomy. Histopathology analysis concluded with a mixed invasive ductal and lobular carcinoma with a grade II of SBR classification that infiltrated the pectoralis major. There were 16 positive axillary lymph nodes out of 24. Then, she had six courses of FEC with no significant side effects.

The patient remained under follow-up and demonstrated no evidence of local recurrence or distant metastasis.

\section{Case 2}

A 48-year-old Tunisian woman with a 15 -year past medical history of a right breast cancer. The lesion measured $20 \mathrm{~mm}$ in diameter. The patient underwent conservative breast surgery in another department. Histological examination showed an invasive ductal carcinoma, grade I of SBR, and 16 negative lymph nodes. She was then treated by chemotherapy and radiation therapy. The patient was referred to our department for a 2-month left axillary nodule. On physical examination, we found a $20 \mathrm{~mm}$ firm nodule with ill-defined boundaries in the left axilla.

Mammography showed an ectopic breast speculated opacity of $15 \mathrm{~mm}$ in size (Fig. 1).

The left axilla mass's core biopsy was concordant with an invasive ductal carcinoma with an SBR grade III. The patient underwent wide excision of the left ectopic breast tissue and a lymph node dissection. Histopathology confirmed the diagnosis of EBC revealing a $25 \mathrm{~mm}$ invasive ductal carcinoma with a grade III of SBR classification, positive HER status (score: $3+$ ), and negative hormonal receptors (ER, PR). There was only 1 metastatic axillary node out of 13 . 


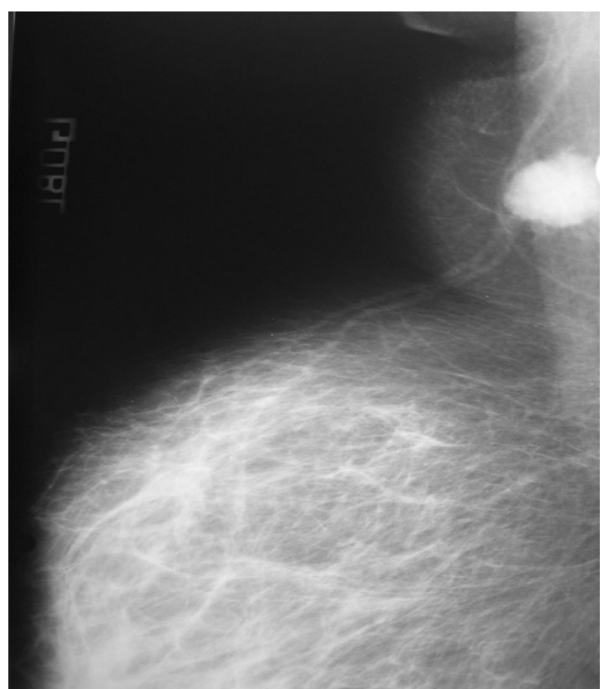

Fig. 1 Mammography revealing an ectopic breast ill-defined opacity. A thoracic-abdominal-pelvic scan did not detect any distant metastasis. We staged the tumor as T2N1M0 according to the TNM system

According to a multidisciplinary meeting decision, the patient received six courses of FEC chemotherapy succeeded by locoregional radiotherapy, including 50 Gy given to the right breast area, the chest wall, and the internal mammary nodes with a subsequent boost of 12 Gy for the tumor bed.

The patient is still under follow-up with no evidence of local or distant relapse.

\section{Case 3}

A 53-year-old Tunisian woman with no past medical history consulted for a right axillary mass developed over the last 4 months. Physical examination revealed a 30-mm firm nodule with unclear limits in the left axilla associated with ipsilateral suspicious lymphadenopathies.

The mammography did not detect any abnormality. The thoracic-abdominal-pelvic scan was free of other distant lesions. The diagnosis of invasive ductal carcinoma was confirmed by the core biopsy of the axilla mass. The tumor was staged as T2N1M0.

The patient underwent wide excision of the right ectopic breast tissue with broad margins and an axillary lymphadenectomy. The histopathologic examination concluded a 22-mm invasive ductal carcinoma, with a grade III of SBR classification, positive HER status (score: $2+$ ), and negative hormonal receptors.

Then, the patient received six courses of FEC-based chemotherapy. After that, a cycle of radiotherapy was administrated (total dosage of $62 \mathrm{~Gy}$ ), including 50 Gy

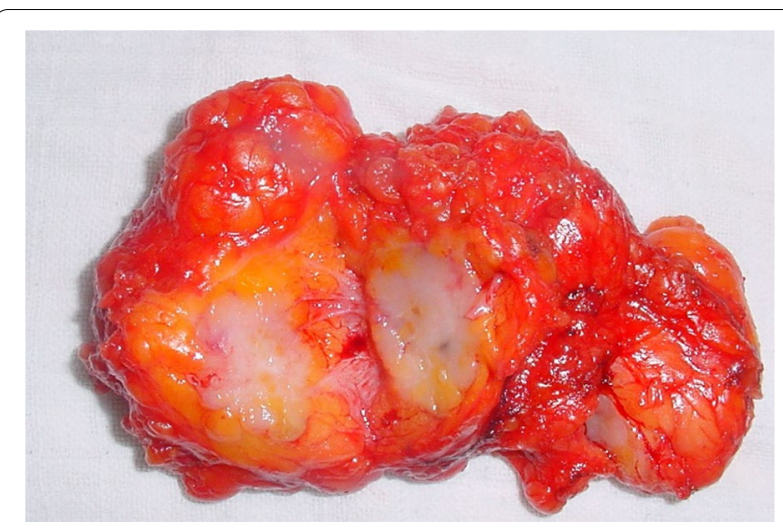

Fig. 2 Surgical excision of the ectopic gland containing a tumor nodule of $15 \mathrm{~mm}$

to her right breast, the chest wall, and the internal mammary nodes, followed by a boost of 12 Gy for the tumor bed.

After a 2-year follow-up, the patient is in a good state without any evidence of local recurrence or distant metastasis.

\section{Case 4}

The patient, a 60-year-old Tunisian woman with no past medical history, presented with a 12-month history of a right axillary nodule. We found an $18-\mathrm{mm}$ firm nodule in the right axilla on physical examination, which was not well defined. There were suspicious associated axillary lymphadenopathies.

The breast mammogram was regular. A thoracicabdominal-pelvic scan did not show distant metastasis.

The patient underwent a core biopsy of the axilla nodule, and histopathology showed an invasive ductal carcinoma. The tumor was staged as T1N1M0. The patient underwent wide excision of the ectopic breast nodule and a right axillary lymphadenectomy (Fig. 2).

The histologic type was of invasive ductal carcinoma of $15 \mathrm{~mm}$ in size with a grade II of SBR classification and both positive HER status (score: $1+$ ) and hormonal receptors.

According to the decision of a multidisciplinary meeting, the patient received six FEC chemotherapy courses, followed by radiation treatment with 50 Gy to her right breast, the chest wall, and the internal mammary nodes, succeeded by a boost of 12 Gy for the tumor bed. The patient also received endocrine therapy by tamoxifen.

After a regular follow-up, the patient relapsed with hepatic metastasis that occurred 28 months later.

The patient underwent FEC-based chemotherapy with no significant side effects. After that, she was lost to follow-up. 


\section{Case 5}

A 33-year-old Tunisian woman with no past medical or family history consulted for a 1-month right axillary nodule. Physical examination showed a $30-\mathrm{mm}$ firm nodule in the right axilla.

The breast examination showed no abnormalities. There were no associated lymphadenopathies.

A mammogram was performed, revealing an ectopic breast ill-defined opacity.

There were no distant metastases on CT scan. The tumor was staged as T2N0M0.

The patient underwent a right lumpectomy, and the frozen section concluded to the diagnosis of medullary carcinoma. Thus, we conducted a wide resection of the ectopic breast tissue with a lymph node dissection. Histological examination confirmed the diagnosis of medullary carcinoma of $25 \mathrm{~mm}$ in diameter with broad safety margins. All the lymph nodes were negative on histologic analysis. There was no expression of hormonal receptors.

The patient received cyclophosphamide, methotrexate, and fluorouracil (CMF)-based chemotherapy associated with radiation treatment with 50 Gy to her right breast, the chest wall, and the internal mammary nodes, followed by a boost of 14 Gy for the tumor bed.

The patient is still in remission after 10 years of follow-up.

\section{Discussion}

There are two types of ectopic breast tissues: supernumerary breast tissue and aberrant mammary tissue $[3,8]$. Supernumerary breasts comprise a nipple, an areola, and a mammary gland, whether isolated or associated [1].

Their reported frequency differed among various ethnic groups ranging between $0.6 \%$ and $6 \%[1,2]$. Concerning the aberrant breast tissues, they have neither a nipple nor an areola, and they usually do not involve an organized secretory system [1]. They generally occur close to the breasts [1]. The axilla represents the most common site, while the sternum area, the infraclavicular region, the epigastrium, and the vulva have also been described [1, 3, 9]. Evans et al. described that ectopic breast tissue is present in the axilla in $71 \%$ of cases [4]. Similarly, Marshall et al. mentioned that the axilla was involved in 58\% of cases, followed by the sternum region in $18.5 \%$, subclavicular area in $8.6 \%$, submammary area in $8.6 \%$, and the vulva in $4 \%$ [1]. They are associated with a frequency that varied between $1.7 \%$ and $6 \%$ [10]. Like the breast tissue in its anatomical position, the ectopic mammary tissue can undergo physiological changes related to menstrual cycle phases, pregnancy, and even the lactation period $[3,9]$.

The EBC represents a rare disease, accounting for about $0.3 \%$ of all breast carcinomas $[4,5]$. It was first described in 1861, and since then, fewer than 200 cases have been reported through literature, affecting mostly the aberrant breast tissue [1]. All of the above publications were isolated cases [11].

A comparison of our results and those reported in the literature are displayed in Table 2. We report in Table 2 the essential studies describing more than one isolated case.

The primary location reported was the axilla in twothirds of the cases and the chest wall and vulva in the remaining reports [5]. This disease is difficult to identify preoperatively owing to its scarcity.

It presents mainly as a firm ill-defined mass developed within the ectopic breast tissue. This lesion may be challenging to distinguish from benign axillary masses (lipoma, tuberculosis, reactive lymphadenopathy) or malignant ones (nodal metastasis, adnexal tumors) [5, 12-15].

The imaging findings demonstrated an aspect of the ectopic breast tissue that is identical to that of the breast [16]. Mammography with its oblique and craniocaudal views represents the best incidence angles as the $\mathrm{EBC}$ is present in the axilla [16]. However, it may not always be helpful [17]. The EBC appears as an ill-defined speculated opacity within the ectopic breast tissue, independent of the orthotropic breast. Further exploration by ultrasound tests may be beneficial for tumors located at distal sites that are not detected by mammography's oblique incidence [18].

The diagnosis of EBC is confirmed histologically, demonstrating ductal carcinoma in most cases, whereas all the other histologic subtypes can be present (lobular, medullary, papillary...) [5, 6]. A review of the literature of EBC made in Japan demonstrated that medullary, mucinous, and apocrine carcinoma were more frequently encountered than pectoral breast cancer [17]. In addition to that, Marshall et al. noted that the distribution of histological types was as follows: $79 \%$ of invasive ductal carcinomas, $9.5 \%$ of lobular carcinomas, and $9.5 \%$ of medullary carcinomas [1]. In our series, we described one case of invasive medullary carcinoma and another one of lobular carcinoma. Histologic similarities between EBC and benign adnexal tumors increase difficulties in making the right diagnosis [5]. Immunohistochemistry may help attest to hormonal receptors' status for estrogen and progesterone, which are negative in adnexal tumors [5].

The surgical treatment consisted initially of a mastectomy along with the ectopic breast tissue and lymph node dissection. However, encouraging survival outcomes were described among patients treated only by wide excision of the ectopic gland [4, 5]. Evans et al. did not demonstrate any survival advantage for a radical mastectomy when compared with local excision and 
Table 2 A comparison of our results and those reported in the literature

\begin{tabular}{|c|c|c|c|c|c|}
\hline Authors & $\begin{array}{l}\text { Number of } \\
\text { cases }\end{array}$ & Age & Histology & Treatment & Follow-up \\
\hline Mornard et al. [24] & 2 & $36-62$ & & & \\
\hline Razeman et al. [25] & 28 & & & $\begin{array}{l}\text { 4: R Mastect } \\
\text { 13:WE+LND }\end{array}$ & 10 recurrences ( 2 years) \\
\hline Erdman et al. [26] & 3 & & & & \\
\hline Khan et al. [27] & 3 & & & $\begin{array}{l}\text { 1: R Mastect } \\
\text { 2: M Mastect }\end{array}$ & $\begin{array}{l}\text { 1: Recurrence-free (9 years) } \\
\text { 2: Lost from view }\end{array}$ \\
\hline Badejo et al. [28] & 2 & & & 2: R Mastect & 2: Recurrence free ( 2 and 4 years) \\
\hline Marino et al. [29] & 2 & & & $2: \mathrm{WE}+\mathrm{RT}$ & 2: Recurrence free (3 years) \\
\hline Kawahara et al. [30] & 59 & $31-84$ & $\begin{array}{l}37 \mathrm{IDC}+3 \mathrm{MC}+ \\
1 \mathrm{ApC}+2 \mathrm{MuCi} \\
\mathrm{C}+1 \mathrm{MCIS}\end{array}$ & $\begin{array}{l}\text { 26: WE+LND } \\
\text { 26: R Mastect } \\
\text { 2:WE }\end{array}$ & $\begin{array}{l}\text { 5: Nod. Recurrence } \\
\text { 54: Recurrence free ( } 1 \text { month to } 13 \text { years) }\end{array}$ \\
\hline Haddad et al. [31] & 2 & & $1 \mathrm{ILC}+1 \mathrm{U}$ ADK & $\begin{array}{l}\text { 1: neoadj CT+ WE+LND + RT } \\
\text { 1:WE+LND + CT + RT + HT }\end{array}$ & $2:$ Recurrence free (1 year) \\
\hline Yanagi et al. [17] & 94 & $26-88$ & $\begin{array}{l}52 \mathrm{IDC}+5 \mathrm{MC}+ \\
2 \mathrm{ILC}+5 \mathrm{MuCi} \\
\mathrm{C}+4 \mathrm{ApC}\end{array}$ & $\begin{array}{l}\text { 6: neoadj CT + WE + LND or Mastect } \\
\text { 84: Surgery (49 WE+ } 1 \text { WE+LND+ } 3 \mathrm{R} \\
\text { Mastect + } 18 \mathrm{M} \text { Mastect + others) } \\
\text { 72: adj treatment (RT +/-CT +/- HT) }\end{array}$ & $\begin{array}{l}\text { 9: Recurrences ( } 3 \text { nodal }+2 \text { local }+2 \\
\text { bone }+1 \text { systemic }+1 \text { peritoneal } \\
\text { cavity) }\end{array}$ \\
\hline Our series & 5 & $33-60$ & $\begin{array}{l}3 \mathrm{IDC}+1 \mathrm{ILC} \\
1 \mathrm{MC}\end{array}$ & $\begin{array}{l}\text { 1: CT+RT } \\
4: W E+L N D+C T+R T \\
+/-H T\end{array}$ & $\begin{array}{l}\text { 1: Metastasis ( } 2 \text { years) } \\
\text { 4: Recurrence free }\end{array}$ \\
\hline
\end{tabular}

ILC invasive lobular carcinoma, IDC invasive ductal carcinoma, MC medullary carcinoma, MuciC mucinous carcinoma, Ap C apocrine carcinoma, MC IS medullary carcinoma in situ, $R$ Mastect radical mastectomy, WE+LND wide excision + lymph node dissection, M Mastect modified mastectomy, neoadj neoadjuvant, adj adjuvant, $R T$ radiation therapy, $C T$ chemotherapy, $H T$ hormone therapy

lymphadenectomy [4]. Cogswell et al. discovered that local recurrence can occur with both surgical procedures [10].

Thus, wide surgical excision with broad margins associated with an axillary lymphadenectomy represents the preferred treatment $[4,5,7]$. Nevertheless, it should be noted that no data are comparing both surgical modalities.

Concerning the adjuvant treatment of EBC, it has the same indications as the breast carcinoma in its anatomical position $[1,5,7,18,19]$.

Some authors consider that the prognosis of EBC is unclear because of the lack of data concerning the follow-up $[4,7]$. Others reported that EBC was carrying a prognosis comparable to that of breast carcinoma at the same stage of the disease [18]. However, EBC may spread to regional lymph nodes earlier than breast carcinoma [8, $15,20,21]$. This could be explained by the fact that the tumor is close to lymph node relays and the diagnostic delay [20]. In the review literature of 94 Japanese patients, lymph node metastasis was found in $51.8 \%$ of cases [17]. Correspondingly, Marshall et al. reported a rate of $46 \%$ of positive axillary lymph nodes [1]. In our series, four patients out of five presented lymph node metastasis despite the tumor's small size. Visconti et al. described that the most affected lymph nodes are homolateral axillary ones and supraclavicular nodes [11].
Due to the scarcity of this disease, we believe that a prophylactic excision may be recommended in patients with risk factors of breast cancer in whom close monitoring is not easy, especially without any functional or aesthetic outcomes [22]. On the other hand, Roorda et al. consider that prophylactic excision of all the ectopic breast glands is mandatory as EBC has a poor prognosis [23].

\section{Conclusion}

EBC represents a rare neoplasm, accounting for $0.3 \%$ of all breast malignancies. Radiological findings and surgical management of any axillary mass developed within the ectopic breast tissue enable the right diagnosis to be made earlier. Further studies are required to describe this disease's epidemiologic aspect and give a higher grade of recommendation for its management.

\section{Acknowledgements}

The paramedical team of the surgery department of the Institut Salah Azaiez for their continuous efforts.

\section{Authors' contributions}

SS, MG, IM: data collection, drafted the manuscript. MC, JBH: review of the literature. JBH, RC, KR: drafted the manuscript. All authors read and approved the final manuscript.

\section{Funding}

No source of funding 


\section{Availability of data and materials}

All the data used were taken from the patient's medical folder available at our institution's archive.

\section{Declarations}

Ethics approval and consent to participate

The authors declare no conflicts of interest, and that this work was done with all due respect to the code of ethics under the supervision of the medical and ethics committee of the Salah Azaiez Institute.

\section{Consent for publication}

Written informed consent was obtained from the patients for publication of this case report and any accompanying images. A copy of the written consent is available for review by the Editor-in-Chief of this journal.

\section{Competing interest}

None.

Received: 11 February 2021 Accepted: 29 June 2021

Published online: 31 July 2021

\section{References}

1. Marshall MB, Moynihan JJ, Frost A, Evans SRT. Ectopic breast cancer: case report and literature review. Surg Oncol. 1994;3(5):295-304.

2. Aubert JP, Paulhe P, Magalon G. Glande mammaire surnuméraire: un cas inhabituel. In Annales de chirurgie plastique et esthétique. 1991;36(5): 457-459.

3. Amsler E, Sigal-Zafrani B, Marinho E, Aractingi S. Ectopic breast cancer of the axilla. In Annales de dermatologie et de venereologie 2002;129(12): 1389-1391.

4. Evans DM, Guyton DP. Carcinoma of the axillary breast. J Surg Oncol. 1995:59(3):190-5.

5. Aviléslzquierdo J, Martínez Sánchez D, Suárez Fernández R, LázaroOchaita $P$, Isabel Longo-Imedio M. Pigmented axillary nodule: carcinoma of an ectopic axillary breast. Dermatol Surg. 2005;31(2):237-9.

6. Shin SJ, Sheikh FS, Allenby PA, Rosen PP. Invasive secretory (juvenile) carcinoma arising in ectopic breast tissue of the axilla. Arch Pathol Lab Med. 2001;125(10):1372-4.

7. Fracchioli S, Puopolo M, De La Longrais IR, Scozzafava M, Bogliatto F, Arisio R, et al. Primary "breast-like" cancer of the vulva: a case report and critical review of the literature. Int J Gynecol Cancer. 2006;16(Suppl 1):423-8

8. Copeland MM, Geschickter CF. Diagnosis and treatment of premalignant lesions of the breast. Surg Clin North Am. 1950;30(6):1717-41.

9. Routiot T, Marchal C, Verhaeghe JL, Depardieu C, Netter E, Weber B, Carolus JM. Breast carcinoma located in ectopic breast tissue: a case report and review of the literature. Oncol Rep. 1998;5(2):413-20.

10. Cogswell HD, Czerny EW. Carcinoma of aberrant breast of the axilla. Am Surg. 1961;27:388

11. Visconti G, Eltahir Y, Van Ginkel RJ, Bart J, Werker PM. Approach and management of primary ectopic breast carcinoma in the axilla: where are we? A comprehensive historical literature review. J Plast Reconstr Aesthet Surg. 2011;64(1):e1-11.

12. Walker AN, Fechner RE. Papillary carcinoma arising from ectopic breast tissue in an axillary lymph node. Diagn Gynecol Obstet. 1982;4(2):141-5.

13. Burdick AE, Thomas KA, Welsh E, Powell J, Elgart GW. Axillary polymastia. J Am Acad Dermatol. 2003;49(6):1154-6.

14. Rho JY, Juhng SK, Yoon KJ. Carcinoma originating from aberrant breast tissue of the right upper anterior chest wall: a case report. J Korean Med Sci. 2001;16(4):519.

15. Giron GL, Friedman I, Feldman S. Lobular carcinoma in ectopic axillary breast tissue. Am Surg. 2004;70(4):312.

16. Adler DD, Rebner M, Pennes DR. Accessory breast tissue in the axilla: mammographic appearance. Radiology. 1987;163(3):709-11.

17. Nihon-Yanagi Y, Ueda T, Kameda N, Okazumi S. A case of ectopic breast cancer with a literature review. Surg Oncol. 2011;20(1):35-42.

18. Jalali U, Dhebri A, Karip E, Hunt R. Ectopic breast carcinoma presenting as sebaceous cyst left axilla. BMJ Case Rep. 2019;12(1):e224789.

19. Guerry RL, Pratt-Thomas HR. Carcinoma of supernumerary breast of vulva with bilateral mammary cancer. Cancer. 1976;38(6):2570-4.

20. Nakao A, Saito S, Inoue F, Notohara K, Tanaka N. Ectopic breast cancer: a case report and review of the Japanese literature. Anticancer Res. 1998;18(5B):3737-40.

21. Vargas J, Nevado M, Rodriguez-Peralto JL, De PA. Fine needle aspiration diagnosis of carcinoma arising in an ectopic breast. A case report. Acta Cytol. 1995;39(5):941-4.

22. Francone E, Nathan MJ, Murelli F, Bruno MS, Traverso E, Friedman D. Ectopic breast cancer: case report and review of the literature. Aesthet Plast Surg. 2013;37(4):746-9.

23. Roorda AK, Hansen JP, Alfred Rider J, Huang S, Rider DL. Ectopic breast cancer: special treatment considerations in the postmenopausal patient. Breast J. 2002;8(5):286-9.

24. Mornard P. Surdeux de tumeurs maligne des mammelles axillaires aberrants. Bull Mem Soc Chir Paris. 1929:21(10):487.

25. Razemon P, Bizard G. Destumerus mammar es aberrantes. Rev Chir. 1929:67:226-62.

26. Erdmann JF, Rec M. Tumors of the breast. Med Rec. 1934;140:583-8.

27. Khan T, James CR, White JE. Tumors of extramammary breast tissue. J Natl Med Assoc. 1982:74(1):37.

28. Badejo OA. Fungating accessory breast carcinoma in Nigerian women. Trop Geogr Med. 1984;36(1):45-9.

29. Marino G, Scarpati D. Breast carcinoma in an atypical site. Problems of staging and treatment. Minerva Ginecol. 1984;36(10):623-623.

30. Kawahara F, Noguchi M, Yamamichi N, Konishi F, Yagasaki R, Minami M, et al. Ectopic breast cancer: two case reports and review of the Japanese literature. Breast Cancer. 1997;4(1):43-8.

31. Haddad H, Bourhaleb Z, El TH, Mezouar L, El MH. Breast cancer in ectopic breast tissue: report of 2 cases. Pan Afr Med J. 2012:13:50-50.

\section{Publisher's Note}

Springer Nature remains neutral with regard to jurisdictional claims in published maps and institutional affiliations.

Ready to submit your research? Choose BMC and benefit from

- fast, convenient online submission

- thorough peer review by experienced researchers in your field

- rapid publication on acceptance

- support for research data, including large and complex data types

- gold Open Access which fosters wider collaboration and increased citations

- maximum visibility for your research: over 100M website views per year

At BMC, research is always in progress.

Learn more biomedcentral.com/submissions 